Relations industrielles

Industrial Relations

\title{
Bélanger, Jacques, P.K. Edwards and Larry Haiven, eds. Workplace Industrial Relations and the Global Challenge
}

\section{Mark Thompson}

Volume 51, numéro 2, 1996

Nouveaux modèles de négociation, de résolution de conflits et de solutions conjointes de problèmes

New Models of Negotiations, Dispute Resolution and Joint Problem

Solving

URI : https://id.erudit.org/iderudit/051102ar

DOI : https://doi.org/10.7202/051102ar

Aller au sommaire du numéro

Éditeur(s)

Département des relations industrielles de l'Université Laval

ISSN

0034-379X (imprimé)

1703-8138 (numérique)

Découvrir la revue

Citer ce compte rendu

Thompson, M. (1996). Compte rendu de [Bélanger, Jacques, P.K. Edwards and Larry Haiven, eds. Workplace Industrial Relations and the Global Challenge]. Relations industrielles / Industrial Relations, 51(2), 417-418.

https://doi.org/10.7202/051102ar

Tous droits réservés @ Département des relations industrielles de l'Université Laval, 1996
Ce document est protégé par la loi sur le droit d'auteur. L’utilisation des services d'Érudit (y compris la reproduction) est assujettie à sa politique d'utilisation que vous pouvez consulter en ligne.

https://apropos.erudit.org/fr/usagers/politique-dutilisation/ 


\section{Recensions}

\section{Book Reviews}

\section{Workplace Industrial Relations and the Global Challenge}

edited by Jacques BélANGER, P. K. EDWARDS and Larry HAIVEN, Ithaca, N.Y.: ILR Press, 1994, ix, 325 p, ISBN 0-87546-327-4 (alk. paper) 0-87546-328-2 (pbk: alk. paper).

Research on North American industrial relations traditionally has paid scant attention to workplace behaviours. In part, this neglect is due to the emphasis on written agreements in the practice and study of collective bargaining in this region. Contemporary North American social science emphasizes large data sets and sophisticated analyses of data, methodologies ill suited to research on these issues, which is based on ethnographic techniques and case studies. The small volume of research in Canada and the United States is usually done by sociologists who have little contact with industrial relations scholars and who seldom publish in industrial relations journals.

Bëlanger, Edwards and Haiven set out to correct these deficiencies with this book. All of the editors were or are connected with the Industrial Relations Research Unit at Warwick University in England, where researchers are much more experienced with research at the level of the workplace. The project grew out of a 1991 conference on the subject at Laval University. By publishing the book in the American press with the largest list of industrial relations books, the editors were assured of a wide audience. Beyond calling attention to this neglected area of research, they also wanted to treat workplace issures from a comparative perspective, an unusual event.

The book centres on chapters that analyze labour relations in the workplace from a comparative perspective: three comparing Canada with the U.S. and Britain, one contrasting Austria and Germany, one discussing plants in four countries owned by the same American multinational corporation, a review of technological change in four countries, and single-country studies on two developing countries, Mexico and Singapore. The editors contributed two comparative chapters. As the editors point out, all of the workplaces studied were factories with predominantly male workforces, except for the Singapore electronics factory.

The rich data in this book do not lend themselves to succinct summaries, but from the perspective of someone trained in the traditional North American emphasis on formal structures of labour management relations, several themes emerge. Even under a system of comprehensive collective agreements in North America, workers and managers reach informal accommodation on many issues, especially the quantity of work to be performed. Bélanger found job control practices in Quebec were quite similar to those in Britain, despite the profound differences in the two industrial relations systems. Quebec workers enjoyed a high degree of autonomy in controlling their work under a typical North American collective agreement. Herzenberg, using grievance and ethnographic data, found that workers negotiated workplace issues with management in auto parts plants in the U.S. and Canada. Reading this 
material, one is struck by the lack of any references to such phenomena in traditional North American industrial relations literature, a deficiency that clearly deserves to be rectified.

As the title indicates, globalization is a theme of the book. Frenkel studied employment relations in U.S.-owned plants in Malaysia, Taiwan, Australia and Britain. The parent corporation emphasized effective management of human resources. The Australian and Malaysian plants made similar products. Yet overall, the differences among the plants outweighed the similarities in their workplace relations. Shire demonstrated significant differences between workplace relations in Germany and Austria. Globalization may be driving many corporate decisions, but its impact on workplace industrial relations is surprisingly small, a fact the editors appear to accept reluctantly.

Several studies in the book demonstrate the subtle ways in which trade unions exercise power. Smith compared the pattern of technological change during the 1980s in Britain, Germany, Italy and Canada. Many readers will be surprised by his conclusion that Italian national agreements and local union strength give labour there greater influence over technological change than unions in the other three countries. Haiven found that negotiated grievance procedures in Canada provided better protection to weak unions than British tribunals (although stronger unions fared better in Britain), not a surprising conclusion to most North American scholars.

Finally, the two studies of workplaces in developing countries demonstrate that employers must reach understandings with their work forces even in the absence of formal requirements. Chung found that female workers in a nonunion electronics plant in Singapore exerted their power in a variety of ways to limits the demands for production made on them or simply to accommodate themselves to the drudgery of their tasks. An American-owned automobile plant in Mexico recognized an official union that scarcely existed in the workplace. None the less, Shaiken found that workers were dissatisfied with their pay, and they elected a militant leadership slate for their local union. The employer dismissed the militant leaders, but was forced to tolerate high turnover and occasional sabotage when it refused to raise wages.

Overall, this book accomplished its objective of addressing the neglect of workplace industrial relations, especially on a comparative basis. It opens new areas of inquiry in the North American context, especially in settings where unions are weak or do not exist. How would the conclusions reported relate to office or retail settings, for instance? The unitarist assumptions so popular in business and academic circles in the 1990s should be tested by the type of ethnographic research reported in this volume. Conventional industrial relations studies should go beyond their traditional boundaries to examine the parties' actions in the workplace.

The book is written for a specialized audience and would have benefited from more rigorous editing of sometimes ponderous writing styles. However, the bibliography is a comprehensive collection of sources on the subject. Several chapters deserve to be included in graduate course reading lists in industrial relations or industrial sociology.

MARK THOMPSON

Faculty of Commerce and

Business Administration University of British Columbia 